\title{
CERTAINTY OF LAW FOR NOTARY CANDIDATES IN REGIONS THAT ESTABLISH THE LARGE-SCALE SOCIAL RESTRICTIONS IN EAST JAKARTA CITY
}

\author{
Muhammad Maghfur Agung, ${ }^{1}$ Sukarmi, ${ }^{2}$ RR. Imam Rachmad Sjafiie ${ }^{3}$
}

\begin{abstract}
The purpose of this article is discussing the law problem that has relations to certainty of law for notary candidates in regions that establish large-scale social restrictions. WHO establish the COVID-19 as the Public Health Emergency of International Concern (PHEIC). The spread controlling of Covid-19, the Indonesian government apply several strategies, the one of strategy is Establish large-scale social restrictions. Large-scale social restrictions cause closed the office. Notary candidates apprentice become closed or get free days. The problem is counting the 24 months apprentice of notary candidates if the regions apply the large-scale social restrictions until the office of notary candidates closed for a while. This research is an empiric juridical. The result of this research that use the method above, researcher obtains the answer of the problem that certainty of law for notary candidates in the regions that apply the large-scale social restrictions based on law regulation.
\end{abstract}

Keywords: Certainty of law, apprentice of notary candidates, large-scale social restrictions

\section{The Introduction}

Now, the world in the difficult pressure since the corona virus (Covid19) comes. As we know, in the beginning of 2020, Covid-19 infection be the world problem. The spread controlling of Covid-19, Indonesian government apply several strategies to prohibit Covid-19. Covid-19 give an effect to state stabilization start from economic, education, and many more. Every region has the authority to prohibit Covid-19, the one of the strategy is Establish the large-scale social restrictions.

The determining Local-scale Social Restriction from the government is a prohibit form to avoid Covid-19. The basic law of Local-scale Social Restriction is on Article 59 of Regulation Number 6/2018 about Health Quarantine. The government applies local-scale social restriction,office is close for a while. The regulation that explains about close the office for a while is on The Regulation of Ministry Number 9/2020 Health about Orientation Local-scale Social Restriction to fast handle the COVID-19, Article 13 is the Implementation of Local-scale Social Restrictions includes:

a. Closed for a while for school and office;

b. Restrictions of religion activities;

c. Restrictions of activities in some places or public facilities;

d. Restrictions of social activities and cultures;

e. Restrictions of transportation;

1 Fakultas Hukum Universitas Brawijawa, Email: maghfurmuhammad@gmail.com

2 Fakultas Hukum Universitas Brawijawa, Email: sukarmi@gmail.com

3 Fakultas Hukum Universitas Brawijawa, Email: sjafiie@gmail.com 
f. Restrictions of other activities especially that has relations of defense and securities.

The regulation makes the office close for a while. Close for a while for office except for office or strategic institute that give attendance about defense and securities, public orderliness, food needs, fuel oil and gas, health, economic, financial, communication, industry, export and import, distribution, logistic, and other basic needs.

The Regulation Number 2/2014 about amendment of Regulation Number 30/2004 about notary position Article 1 numeral (1) Notary is public functionary that has the authority to make authentic official documents and has the other authority such as in this regulation or based on other regulation. The authority of notary is make authentic official document. The job of notary in development world now, notary is important for society. The requisite to appointed as the notary based on Article 3 of Regulation Number 2/2014 about amendment the Regulation Number 30/2004 about notary are:

a. Citizen of Indonesia

b. Obedient to God;

c. The minimum age is 27 (twenty seven) years old;

d. Healthy body and spiritual that prove based on healthy letter by doctor or psychiatrist;

e. Bachelor of law and graduate in strata two of notary;

f. Already do the apprentice or working as the notary staff for minimum 24 (twenty four) months in a row in the notary office after graduate in strata two of notary;

The notary candidates have to fulfill the one of requisite in Article 3 on Notary Regulation letter $f$, the requisite is apprentice or working as the notary staff for minimum 24 (twenty four) months in a row in the notary office as the self-initiative or recommendation from Notary Organization after graduate in strata two of notary.

In the Covid-19 pandemic in region without local-scale social restrictions, there is no problem since no close for a while in the office. However, for region with local-scale social restrictions, there is close for a while in the office. Based on Article 13 Section (3) The Regulation of Health Ministry Number 9/2020, Notary office is not the part of working place that have to close for a while. East Jakarta City applies the Local-scale Social Restrictions. The notary candidates is not the employee in the notary office, however they have responsibility to apprentice. Therefore, the notary candidate has to obey all of the rules in the apprentice place of candidate.

From the explanation, candidate of notary apprentice in every region that applies local-scale social restrictions has multiple interpretations about office hours of notary candidate apprentice. In the Regulation of Notary, there is not specific explain about office hours in the notary office. The Article 59 Section (1) The Regulation Number 6/2018 about Health Quarantine explains that Local-scale Social Restrictions is the part of Emergency Society Health response. When the emergency society health happens, government will close the school and working place, the second are religion activities restrictions, and the third is place activities restrictions or public facilities.

From the explanation, there is a law issues in this research that Regulation of Notary without rules about notary candidate to fulfill the Article 3 letter $\mathrm{f}$ in Regulation of Notary if the regions apply the local-scale 
social restrictions. The vacuum of norm for notary candidate to do apprentice in the local-scale social restrictions region since Regulation of Notary does not manage it. The problem is about calculation of apprentice for notary candidate if the office closes for a while, there is not regulation to manage about apprentice for notary candidate. The problem makes uncertainty of law. Based on the problem, researcher takes this title, Certainty of Law for Notary Candidates in Regions That Establish the Large-Scale Social Restrictions.

\section{Research methods}

The research method in this research is empiric research method. The empiric research method is about research that examines law science using social factor in the law research border. This research needs truth data that proven. Researcher gets the data by research in certainrange to get accurate and factual data appropriate to researcher's aim. To get accurate and factual data, researcher has to use research method. According to Sugiyono, in general, research method as the scientific way to get data with certain aim and purpose.

\section{Discussion and Results}

\section{The Certainty of Law of Apprentice Implementation For Local-scale Social Restrictions Region.}

The administrative city of East Jakarta is the name of city in the east Special Capital Region of Jakarta.The notary office is the place of Notary to do their administrative job. The notaries in East Jakarta are 168 notaries.

The Presidential Decree Number 12/2020 about Unnatural Disaster of Spreading Corona Virus Disease 2019 (COVID-19) as the national disaster based on law regulation that Covid-19 in Indonesia belongs to national disaster. The implementation of local-scale social restriction is the idea of Governor/regent/mayor to ministry that organize health department. Ministry of health determines the local-scale social restrictions with pay attention to Head of COVID-19 Response Acceleration Task Force opinion.

The implementation of local-scale social restrictions in Special Capital Region of Jakarta Province based on Ministry Health Decree of Indonesia Republic Number HK01.07/MENKES/239/2020 determine the local-scale social restriction in Special Capital Region of Jakarta Province as the way to handling acceleration of Corona Virus Disease 2019 (COVID-19). Based on the regulation, Jakarta Governor releases the Governor Regulation of Special Capital Region of Jakarta Number 33/2020 about the social restrictions implementation in the huge scale to Handling the Corona Virus Disease (Covid-19) in Special Capital Region of Jakarta at 9 April 2020. Based on the regulation about local-scale social restrictions in province area, East Jakarta follows the regulation that determine of province government. Then the implementation of local-scale social restrictions is happen in East Jakarta.

The certainty of law is a law guarantee with justice contain. The norms that develop justice have to function as the obedient regulation. In the forming of law regulation, create the main principle to make law regulation clear, the principle is certainty of law (Julyano, 2019). According to Gustav Radbruch, justice and certainty of law are permanent parts of law. He give an 
opinion that justice and certainty of law have to noticed, certainty of law have to guard for securities and orderliness of state. Finally, positive law has to orderliness. Based on certainty of law theory and value that want be reach, it is the value of justice and happiness (Ali, 2002: 95).

Based on certainty of law, as the explanation above, the implementation of apprentice notary candidate in every region those apply local-scale social restrictions. Since close for a while for office, not yet certainty regulation that manages it especially in notary regulation about notary apprentice in times of 24 months, then the apprentice notary has responsibility for implementation of apprentice notary candidate. What is the calculation of apprentice time in local-scale social restrictions calculated or not since the emergency health of society happen? Calculated or not of apprentice time for apprentice notary candidate, it is the authority of apprentice receiver of notary.

The implementation of local-scale social restrictions, the office is close for a while. Close for a while is restrictions work process in the office and change it with work from home to keep the productivity of worker. Implementation of local-scale social restrictions do in incubation time maximalist time in 14 days. When in incubation time get the new cases spreading of Corona Virus, the incubation time will be extended until 14 days start from the last cases find. Local-scale social restrictions of East Jakarta include in Special Capital Region of Jakarta. Since the rules determine by Special Capital Region of Jakarta government, the local-scale social restrictions happen in East Jakarta. During the local-scale social restrictions, the government announces to change work from office to work from home. Based on Special Capital Region of Jakarta Governor, the leaders in every office in charge of anything happen in the office.

Notary candidate in East Jakarta when they do the apprentice to fulfill Article 3 letter $\mathrm{f}$ of Notary Regulation (apprentice in local-scale social restrictions region), based on Regulation of Health Ministry and Governor Special Capital Region of Jakarta Regulation, apprentice in the office close for a while or not, it is depend by notary candidate. However, the implementation of close for a while in the notary office is not mention the rules close for a while or excepted. Based on that case, close for a while or work not in the office make multiple interpretations since notary office is not specific explain in the office category. Notary Association of Indonesia administrator in Special Capital Region of Jakarta send letter to province government Special Capital Region of Jakarta at 30 April 2020. Main of the letter number 29/PENGWILDKIJAKARTA/IV/2020 about Governor Regulation that explain about local-scale social restrictions, Notary Association of Indonesia appeal to take Notary position or Land Deed Official include in excepted from close for a while office activity. At 5 May 2020, Special Capital Region of Jakarta government gives their respond about Notary Association of Indonesia administrator appeal. Based on Region Secretary in Special Capital Region of Jakarta Number: 317/-071 explain according to Notary Association of Indonesia appeal, Notary or Land Deed Official can be excluded from close for a while of office activity however every office have to apply the health protocol in the office such as the regulation explain. That appeal letter valid for notary in East Jakarta. Since has been 
agreement with government, administrator in East Jakarta has not 5 to East Jakarta government.

Based on the explanation about implementation of local-scale social restrictions by Regulation Number 6/2018 about Health Quarantine, the health emergency happen makes activity restriction in the certain area. That restriction is respond from health emergency in society. That emergency makes the office close for a while. Implementation of local-scale social restrictions has to appropriate with law regulation. Determine the local-scale social restriction has to determine by government regulation. In general, implementation of local-scale social restrictions has to base on government decree. The explanation makes every region determine by their self about applying the local-scale social restriction absolutely every region have to make coordination with Central Government. The coordination to determine those regions can apply the local-scale social restriction or not. The certainty of law about close for a while for Notary office that not manage in regulation, there is unclear norm of local-scale social restrictions. Uncertainty of law about that case show from the Notary Association of Indonesia appeal from Special Capital Region of Jakarta about the Notary position and Land Deed Official excepted. This case shows the uncertainty of notary office category in government. That case make notary candidate apprentice cannot get clear explanation about calculating apprentice time. When the notary office prohibits office activities, notary candidate apprentice cannot do their apprentice until 24 months in the notary office.

In fact, apprentice in notary office, apprentice of notary candidate as the apprentice receiver. On Article 7 PERKUM Number: 10/PERKUM/INI/2018 the executor and in charge people of notary candidate apprentice is notary who receive the apprentice. The apprentice place of notary candidate is Notary office that receives the apprentice. Apprentice implementation can do for one or more notary office in 24 months and have to pay attention of minimal times in 6 months. Time management for notary candidate apprentice is every work days, minimal time is 4 hours per day. This regulation is a basic implementation of apprentice based on Article 3 letter $\mathrm{f}$ in Regulation Number 2/2014 about amendment the Regulation Number 30/2004 about Notary position. Since the regional decree of localscale social restriction and caused close for a while for office, notary candidate who in apprentice will be close for a while if regulation decide it. However, already submit the excepted appeal by Notary Association of Indonesia in Special Capital Region of Jakarta to Province Government of Special Capital Region of Jakarta, it makes notary office in Jakarta especially in East Jakarta still do their job and not close for a while. For region that apply the local-scale social restriction, Notary Association of Indonesia administrator got the decree that notary office still open, the activity in the office still on going like usual. Although the work activities on going, worker and owner from the office have to apply health protocol, the health protocol consists of:
a. Wear mask;
b. Wash hand using hand soap;
c. Physical distancing minimal 1 meter.

The implementation of health protocol is important to avoid virus spreading. In the work world, decided to apply work from home for worker who has Covid-19 indication. Work from home is a solution from government 
to accelerate the work condition. For notary candidate apprentice in notary office, they can do work from home or not, since work from home implementation for worker.

The certainty of law from notary candidate apprentice in notary office on apprentice calculating for two years is in dangerous since there is no regulation about work from home implementation. Work from home is for worker. Work from home is doing on home of them. In PERKUM Article 1 section (3), Apprentice in notary office is a position implementation of notary candidate in the notary office as the apprentice receiver. The meaning of apprentice is notary candidate have to do apprentice in office as the practice of position implementation and apprentice with work from home method is not manage in regulation, it is make unclear. Based on that regulation, implementation of apprentice has to do in the notary office.

The notary who receive the apprentice is an executor and in charge of notary candidate apprentice in the office. Calculating apprentice time is 24 months, since that is notspecific managein regulation and refers to Article 7 PERKUM Number: 10/PERKUM/INI/2018, calculating apprentice time give to in charge of apprentice, it is mean the notary who receive the notary candidate apprentice, the time include in apprentice time or not, or have another solution.

\section{The Obstacle And Effort of Calculating Two Years Apprentice Time For Notary Candidate Who Do Apprentice In East Jakarta And Get Local-Scale Social Restrictions}

In Covid-19 era, anything changes to be abnormal. The meaning of abnormal here is about activities before Covid-19 is free and now change to be restrict. Health protocol implementations in Covid-19 era are wear mask and physical distancing. Covid-19 influences the implementation of notary candidate apprentice. Local-scale social restriction makes office close for a while. Implementation of local-scale social restriction based on Article 59 Regulation Number 6/2018 About Health Quarantine, main of that regulation is protecting the society health. This regulation committed to avoid health emergency in society. Health Emergency in Society is happen to health society which has extraordinary characteristic with disease infect spreading sign and/or that is happen caused of nuclear radiation, biologic pollution, chemic contamination, bioterrorism, and food that make dangerous for health and potentially spreading across region or state.

Article 1 section (1) Regulation Number 6/2018 about Health Quarantine explain Health Quarantine is effort to avoid and prevent in or out the disease and/or risk factor of society health which potentially make emergency of society health. Principle of this Regulation Number 6/2018 about Health Quarantine consists of:

a. Humanity is implementation of Health Quarantine have to base on protect and homage to polite and universal humanity values;

b. Benefit is Health Quarantine have to give huge benefit to protect national needs in implementation of increase the society health level;

c. Protecting is Health Quarantine have to protect all of society from disease and risk factor of health that potentially create Emergency Health of Society; 
d. Justice is implementation of Health Quarantine have to give average and justice attendance for every people;

e. Non-discriminatory is implementation of Health Quarantine do not makes different treatment base on religion, ethnic group, gender, and social status that give an effect to human rights implementation;

f. Public needs is implementation of Health Quarantine have to make public needs as the first than individual needs;

g. Solid is implementation of Health Quarantine have to do solid involve every sector;

h. Law awareness is implementation of Health Quarantine demand law awareness and loyalty from society;

i. State sovereignty is implementation of Health Quarantine have to make national needs as the first thing and join to increase Emergency Health in Society controlling that potentially create the world restless.

The purpose of implementation of Health Quarantine is for:

a. To protect society from disease and/or Health Risk Factor of Society that potentially makes Emergency Health in society;

b. Avoid and prevent the disease and/or Health Risk Factor of Society that potentially makes Emergency Health in society;

c. Increase the national defense in health society department; and

d. Protecting and give certainty of law for society and health employee.

From the main purposes Regulation of Health Quarantine are protect, avoid, and prevent disease if it happens to society and give law protect and certainty to society. Central government and Regional Government have responsibility to protect society health from disease that makes Emergency Health of Society by implementation of Health Quarantine. Central Government has responsibility to Health Quarantine implementation on enter gate and in the regional according to solidarity. Central Government can involve Regional Government to do Health Quarantine. Central and Regional Government have responsibility to prepare the resources that is important for implementation of Health Quarantine.

Article 7 Regulation Number 6/2018 About Health Quarantine explain every people has right to get similar treatment in implementation of Health Quarantine. Every people have right to get similar basic health treatment appropriate to medic needs, food needs, and habitual life needs when in quarantine. Every people have to obedient and join the implementation of health Quarantine. Central Government can determine the Emergency Health and revoke the Emergency Health. Before determine the Emergency Health in Society, Central Government determines the category of disease and risk factor that will be makes Emergency Health in Society. The step to determine and revoke based on Government Regulation.

The implementation of Health Quarantine for Emergency Health in Society doing by Central Government faster and appropriate base on huge or not the threat, affectivity, resources support, and operational technic consider to state sovereignty, securities, economic, social, and culture. The implementation of Health Quarantine can do coordination and cooperate with another state in this world. Step to prevent the Emergency Health in Society manage by Government Regulation. In this case, Emergency Health in 
Society is an incident which makes world restless. Central government inform to international appropriate with International Regulation. Communication, coordination, and cooperate to identification the cause, indication and sign, influence factor, effect, and step have to do to prevent it.

According to WHO (World Health Organization), Pandemic is new disease spreading to around the world (World Health Organization, 2020). Pandemic is disease epidemic that spreading to wide area, example in several continent, or in around the world. Endemic disease spread with total people of infection stable, it is not pandemic. Epidemic is a disease as the new case of certain human population, in several times, increase out of the amount, based on latest experience. In another word, epidemic is happens faster than expectation. The amount of new cases disease in certain population at certain times is incidence rate of appears disease. In Indonesia Regulation, epidemic is smitten by infect disease in society, the amount of infected people increase unbelievable at certain times and regional, the incident can make disaster. Global pandemic or endemic is the infect disease to people in wider geographic area. According to World Health Organization, pandemic can happen if these three requisite fulfilled:

a. The disease is the new thing in that population;

b. The agent cause disease infected to human and caused sick seriously;

c. The agent cause disease spreading easy and continue to human.

A disease or condition cannot mention as the pandemic because the disease kill many people. The example is cancer makes a huge of death, however that disease is not including in pandemic since the disease not infect. Infect endemic is usually the event that certain disease spreading in society, the amount of people infected is factual increase more than normal condition in certain times and regional, the disease can make disaster. Disease source are human, animals, plants, and another things that polluted by disease, the cases make endemic.

On the history of human, many a huge cases happen about endemic or pandemic. Disease on endemic usually the infect disease by animals that happens together with domestication of animals such as influenza and tuberculosis. These are the example of endemic on history:

a. Bubonic plague or pest is infecting disease on human that cause by enterobakteriaYersinapestis. Pest disease spreading by rodent (especially mouse). This endemic disease more happens in the history and makes a huge death. The dramatic case is Black Death that happens in Europe in the Middle Century;

b. Cholera is infecting disease in digestion, that disease cause by bacterium Vibrio cholera. This bacteria comes to the human body by drinking water that contaminated by false sanitation or eating the unripe fish with false cooking, especially mollusks. The indications of this disease are diarrhea, cramps stomach, feeling loathing, vomit, and dehydrated. The death usually cause by dehydrated. When the infected people cannot get the right treatment, the infected people potentially death. Treatment can do with rehydrated aggressive or regimen, it is usually give to intravenous step by step until the diarrhea stop; 
c. Influenza or flu is an infected disease cause by RNA virus from familiaOrthomyxoviridae (Influenza virus), it is attack fowl and mammals. General indication of this disease are feeling cold, fever, shore throat, feeling painful on the head, cough, feeling tired, and feeling uncomfortable in general.

Based on experience in around the world about infected disease, and then created law regulation to anticipate spreading endemic that potentially will be make death increase. To anticipate the spreading, the government is applying local-scale social restriction to decrease virus spreading. Local-scale social restriction is activity restriction of certain population in certain region that expects get the disease infection until makes a preventive step.

In Indonesia, the Covid-19 pandemic causes the implementation of local-scale social restriction in every region. The one of preventive form is office close for a while. Office close for a while, however except several office that still open, the office still open in local-scale social restriction manage by Regulation of Health Ministry. Close for a while for office give an effect for society in general. The effect makes several entrepreneurs get financial loss on their business. For society, the real effect is Termination of Employment Relationship in various offices. Many sectors get an effect for society, when the area get the direct or indirect damage. Although the certain regions not apply local-scale social restriction, those regions still get the damage of this pandemic.

Economic stabilization becomes an important factor in this pandemic. Governments apply various regulations to keep economic stabilization. Notary office has important part on banking and tax department, from that case expected to not Notary office not close for a while. However the notary office is not included in law regulation, the Notary Association of Indonesia make an appeal letter to government for explain that Notary office and Land Deed Official included on except close for a while. The damage is for notary candidate apprentice. Apprentice for notary candidate consist of two are apprentice in notary office and apprentice together. Applying local-scale social restriction makes work activity in notary office can close for a while. Close for a while depend on law regulation that determine by Regional Government.

If the notary candidate that do apprentice in Notary office has indication of Covid-19, notary candidate cannot comes to the Notary Office since will be given the high risk. It can give damage to another staff or employee. When in the Notary Office find the people with positive Covid-19, the notary office will be close for a while in several days and will be stopped other activity. Function of temporary stop is to disappear the virus in the notary office, when the office close, the office get disinfectant spraying in around of the office to exterminate virus. Notary has responsibility for their office in notary office, which is for fluency office activity. When the employees show the Covid-19 indication, notary will be suggesting taking a rest on home and do WFH (Work from Home). For the notary candidate is not manage about apprentice from home, it is make unclear for apprentice time. Based on experience in the field since the damage of Covid-19, notary candidate in the beginning on February until March 2020, on March 2020, the offices temporary close. When the office is temporary close, all of employee and notary candidate get holiday. It was not instruction for Work from Home in 
the beginning Covid-19. In the beginning Covid-19, East Jakarta society are scare to go out from their home.In the beginning times of Covid-19 pandemic comes to Indonesia on March, office get temporary holiday although in East Jakarta do not apply local-scale social restriction. It is doing by initiative of Notary because the Notary scare to get infected Corona virus.

The decision to apply local-scale social restriction in East Jakarta is valid at 13 April. Based on Regulation of Health Ministry in Indonesia Number HK01.07/MENKES/239/2020, Health Ministry determining localscale social restriction in the Special Capital Region of Jakarta to faster controlling the spreading of Corona Virus Disease 2019 (COVID-19). It is make the Governor Regulation of Special Capital Region of Jakarta Number 33/2020 about The Implementation of Local-scale Social Restriction to Controlling Corona Virus Disease 2019 (COVID-19) in Special Capital Region of Jakarta Province at 19 April 2020.

Although the pandemic of Covid-19 still on going in Indonesia, working activity have to work because Indonesia already have the health protocol likes physical distancing, washing hand, and wear mask to go to work. At 30 April 2020, the governor determines Governor Regulation of Special Capital Region of Jakarta Number 41/2020 about the violation of local-scale social restriction implementation controlling Corona Virus Disease (Covid-19) in Special Capital Region of Jakarta. Office/work place that include in except category of closing for a while program on local-scale social restriction implementation, if the office do not apply health protocol, the leader of that office will be get administrative punishment like warning letter and administrative fine minimal Rp25.000.000,00 (twenty five million rupiahs) and maximalist Rp50.000.000,00 (fifty million rupiahs). Administrative punishment controlled by Department of Labor, Population Resettlement, and Cooperatives accompanying with Regional Staffs. Closing punishment for office/work place valid until local-scale social restriction done.

In that time, notary office has to close for a while. However the notary is the main part in economic department, the Notary Association of Indonesia administrator sending letter to Special Capital Region of Jakarta Province at 30 April 2020. Main of the letter number 29/PENGWILDKIJAKARTA/IV/2020 about Governor Regulation that explain about local-scale social restrictions, Notary Association of Indonesia appeal to take Notary position or Land Deed Official include in excepted from close for a while office activity. At 5 May 2020, Special Capital Region of Jakarta government gives their respond about Notary Association of Indonesia administrator appeal. Based on Region Secretary in Special Capital Region of Jakarta Number: 317/-071 explain according to Notary Association of Indonesia appeal, Notary or Land Deed Official can be excluded from close for a while of office activity however every office have to apply the health protocol in the office such as the regulation explain.

At 4 June 2020, Governor Regulation of Special Capital Region of Jakarta Number 51/2020 about Local-scale Social Restriction in the transition times to health society, secure society, and productive. This regulation determine based on central government regulation for society to apply social distancing. Notary candidate apprentice is confusing with the rules because they are have to do holiday in the beginning of Covid-19 comes to Special Capital Region of Jakarta. The office is close for a while, the time of 
notary candidate apprentice is calculated or not? In the beginning, if the holiday is not because the Covid-19, apprentice time is calculated. Notary expects that Covid-19 will be done faster, however the situation and condition about amount of spreading is faster than Notary expected. It is make the notary consider receiving the notary candidate apprentice because maybe this pandemic will be longer than expected. Main problem is on the regulation of local-scale social restriction, when the notary breaks the rules, the notary will be get punishment. In the Governor Regulation of Special Capital Region of Jakarta, the punishment are administrative punishment like warning letter and administrative fine minimal Rp25.000.000,00 (twenty five million rupiahs) and maximalist Rp50.000.000,00 (fifty million rupiahs) until the government will be closed the office for a while until local-scale social restriction done and in charge of these is the leader of work place. In this case, the leader of work place is Notary. The Notary has responsibility to suggest Work from Home (WFH) if they find the staff with Corona Virus indication. The rule is also valid for notary candidate.

The notary candidate can do the apprentice in the office with negative result of rapid test prove. That condition will be normal if the notary candidate does not show the Covid-19 indication, when notary candidate show the sign of Covid-19 indication, the notary candidate will be work from home until they are healthy. Covid-19 indication will be detected if the notary candidate gets flu, cough, sneezing, and $38^{\circ}$ body temperature, the notary candidates have to take a rest in their home. About the calculating apprentice time, it is still calculated of notary apprentice time, however the notary candidate proactive to do studying from home. Solution of apprentice in the notary office is still studying from home. The requisite of physical practice in the office doing after pandemic done and all of notary candidate have been vaccinated, the activity will be normal after that. When the apprentice time is finish in the pandemic, everything that needs physical ways will be treated with standard operating procedures, for now needs rapid test antigen to do anything. However only for important things likes participation to make official document then become a witness or substitute notary. Based on that explanation above, the problem is when the notary candidate get Covid-19 indication on local-scale social restriction time, the notary candidate will be take a rest in their home.

\section{Conclusion}

The certainty of law about notary candidate apprentice in the area that applying local-scale social restriction is determine local-scale social restriction in the area with emergency health damage, the activity in the office/work place will be close for a while. Based on Regulation of Health Ministry, notary office exclude office category on except category. However the region administrator does appeal submit to the government, from the regional regulation, notary office still open. When the notary office close for a while, notary candidate that doing the notary apprentice will be work from home, when the notary office still open, the notary candidate can do the apprentice like usually in the notary office to fulfill the 2 years requisite.

The problem of calculating 2 years apprentice of notary candidate who doing apprentice in the notary office in East Jakarta is unclear regulation about the calculating apprentice time in Covid-19 pandemic. Effort to 
guarantee the calculating apprentice time of notary candidate is everything depends on Notary who receive the apprentice make rule to apprentice from home, however the notary candidate have to make the result report of their study. However, when they needs come to office, notary candidate have to fulfill health protocol and they are negative Covid-19, it is proven by rapid test.

\section{Suggestion}

In this research, the researcher suggest to House of Representative and the government change the rule of Notary position with adding the rule about implementation of notary candidate apprentice and the technical calculation of notary candidate apprentice do not get multiple meaning about implementation of notary candidate apprentice when the region determine local-scale social restriction until office close for a while happen. That things is a form of certainty of law.

\section{References}

Ali, Achmad. (2002). Menguak tabir hukum (Suatu kajian filosofis dan sosiologis). Penerbit Toko Gunung Agung.

Hadjon, Philipus M. (1987). Perlindungan bagi rakyat di Indonesia. PT.Binallmu.

Hairi, Prianter Jaya. (2020). Implikasi hukum pembatasan sosial berskala besar terkait pencegahan covid-19. Info Singkat Kajian Singkat Terhadap Isu Aktual dan Strategis, Vol. XII, No.7/I/Puslit/April/2020, $1-6$.

Hartono, Sunaryati. (1991). Politik hukum menuju satu sistem hukum nasional'. Alumni.

Julyano, Mario \& Sulistyawan, Aditya Yuli.(2019). Pemahaman terhadap asas kepastian hukum melalui konstruksi penalaran positivism hokum. Jurnal Crepido, Jurnal Mengenai Dasar-Dasar Pemikiran Hukum: Filsafat dan Ilmu Hukum, 1(1),13-22. https://doi.org/10.14710/crepido.1.1.13-22

Muchsin. (2003). Perlindungan dan kepastian hukum bagi investor di Indonesia. Magister Ilmu Hukum Program Pascasarjana Universitas Sebelas Maret.

Marzuki, Peter Mahmud. (2008). Pengantar ilmu hukum. Kencana.

Rato, Dominikus. (2010). Filsafat hukum mencari: memahami dan memahami hukum, LaksbangPressindo.

Rasjidi, Lili \& Putra, I.B Wysa. (1993). Hukum sebagai suatu sistem. Remaja Rusdakarya.

Rahardjo, Satjipto. (2000). Ilmu hukum (5th ed.). Citra AdityaBakti. 